\title{
Analysis on Patriotism Education of College Students Born after 2000 Years
}

\section{Xiaoqin Cui*}

Southwest Jiaotong University, Chengdu, Sichuan, 611756, China

\section{ARTICLE INFO}

Article history

Received: 13 April 2020

Revised: 20 April 2020

Accepted: 9 October 2020

Published Online: 16 October 2020

Keywords:

Post-00s college students

Patriotism

Patriotic education

\begin{abstract}
In September 2018, the post-00s have entered the university as an official group. Due to its typical group characteristics and the emergence of new patriotism, which brings both opportunities and challenges to the patriotic education of post-00s college students, this paper puts forward the requirements of patriotism in the new era through the connotation of patriotism education in the new era. Through the study of the theory course of ideological and political education in colleges and universities, we can educate students to learn rational patriotism, strengthen the education of patriotism on the Internet, and cultivate the spirit of international patriotism.
\end{abstract}

\section{Introduction}

${ }^{6} \mathrm{P}$ atriotism is the core of the Chinese national spirit. Patriotism is deeply rooted in the heart of the Chinese nation. It is the spiritual gene of the Chinese nation. It maintains the unity of all ethnic groups in China and inspires generations of Chinese people to make unremitting efforts for the prosperity and development of the motherland. Over the past five thousand years and more, the Chinese nation has withstood countless unimaginable risks and tests, and maintained its vigorous vitality and passed on from generation to generation. This is inseparable from the profound and enduring patriotic tradition of the Chinese nation., ${ }^{,[1]}$ Patriotism is an indispensable inner spiritual driving force in the process of China's modernization and the source of the power to realize the Chinese dream. Patriotism has strong politi- cal leadership, popular appeal and organizational mobilization. But patriotism is not something you are born with. It is something you are taught, nurtured and practiced. It is of great significance to strengthen the patriotic education of post-00s college students and cultivate and enhance their patriotic enthusiasm.

\section{The Connotation of Patriotism in the New Era and the Requirements of Patriotism Education for Post-00s College Students}

\subsection{Patriotism Is the Rational Sublimation of Patriotic Emotion in Psychology}

Thought and behavior. It is based on people's attachment to their motherland and deep emotion formed in long-term social practice, and reflects the organic unity of profound

*Corresponding Author:

Xiaoqin Cui,

Southwest Jiaotong University, Chengdu, Sichuan, 611756, China;

E-mail:11993038@qq.com. 
patriotic feeling, firm will to serve the country and noble action to serve the country. To strengthen patriotism education, we must first accurately grasp the basic connotation and basic requirements of patriotism. Patriotism is a category of history and class, in different countries and different historical periods have different nature and content, and the content of patriotism is developing with The Times. Chairman Mao once pointed out: "the specific content of patriotism depends on what kind of historical conditions. ${ }^{,[2]}$ In the new era, the situation of the country and the world are undergoing drastic changes, and some new contents have been injected into patriotism, and new requirements have been put forward for the education of patriotism.

\subsection{The Content Is More Richer}

The new era of patriotism is the core of the Chinese national spirit, its bright era theme is "China dream" to realize the great Renaissance of China, its essence is to insist on his patriotism and love the party, the socialist unity, its mission is to safeguard the unity of the motherland and national unity, is based on national and facing the world, should not only respect and inheritance of the Chinese nation excellent culture, and is good at seek wisdom, absorbing nutrition from different civilizations and enhance the vitality of the Chinese civilization to life, for the development of world peace and human destiny community who contribute to the building. Patriotism in the new era is the inheritance of the Chinese patriotic tradition and the promotion of the patriotic spirit of saving the nation from extinction and surviving since modern times. It adheres to the position and principle of Marxism, and creatively discusses a new patriotic system that does not forget the original, absorbs the external and focuses on the future with the viewpoint and method of Marxism. It not only bases itself on its own country, but also looks to the world. It not only inherits the excellent ancient culture, but also has the courage to develop the great cause of today.

\subsection{With the Rich Connotation of Patriotism, New Requirements Are Put Forward for the Patriotic Education of the Post-00s Generation}

Strengthen the sense of responsibility education for post00s college students. Let them feel the responsibility on their shoulders, and consciously strive for the prosperity of the country, the rejuvenation of the nation and the happiness of the people.

It is necessary to cultivate the awareness of resolutely safeguarding national unity and ethnic unity, and clearly oppose any attempt to split the country or undermine na- tional unity.

We should break with narrow national patriotism, inherit and disseminate the fine Chinese culture, seek wisdom and nutrients from different civilizations, enhance the vitality of the Chinese civilization, and strive to maintain world peace and build a community with a Shared future for mankind.

In short, the patriotism education for college students after 00, as on May 2, 2018, Xi Jinping, teachers and students from Beijing University symposium speech: patriotism, cannot stay on the slogan, to take root in the people, dedication, always think of countries, the thought of people everywhere, do "love of feeling emigre, pollution Yu Guozhe evil". Patriotism should not rest on slogans, but on putting one's ideals into close contact with the future of the motherland and one's life with the destiny of the nation, taking root in the people, devoting oneself to the country, and putting patriotism into practice in one's actions.

\section{The Importance and Necessity of Patriotism Education for Post-00s College Students}

Era of patriotism education has an important value: patriotism is the core of the spirit of the Chinese nation, is an important ideological basis of the development of the Chinese nation, is also a powerful impetus to realize the great rejuvenation of the Chinese nation, and patriotic education to improve college students' ideological and moral levels after 00 , realize personal value has important meaning in life. However, due to various reasons, the patriotic education of post-00s college students has brought challenges, so it is necessary to strengthen their patriotic education.

\subsection{The Environmental Changes Faced by Post- 00s College Students Need to Strengthen Patriotic Education.}

\subsubsection{Born and Growing Up in the 21st Century, the Post-00s Generation Is A New and Great Century}

This is the era when the wave of globalization started the global village, but it is also a complicated and rapidly changing era. "This is the best of times, but also the worst of times," xi said, using the dictum of Charles Dickens. "With the advent of the era of globalization, the patriotic education of nation-states (i.e., developing countries) has encountered unprecedented challenges, and the concepts of state sovereignty, region, politics and culture, and nation-states, which are the basis of the patriotic educa- 
tion of nation-states, have been attacked and eliminated to different degrees ${ }^{[3]}$. With the deepening of economic, scientific and technological globalization and the construction of "One Belt And One Road", China has gone global from introduction to strengthening exchanges and cooperation with other countries in the world. Xi Jinping in January 18, 2017, in the United Nations headquarters in Geneva "together to discuss human destiny community" high-level meeting, the human fate community win-win sharing scheme is proposed, it can make the traditional national boundaries is broken gradually, national or state sovereignty has lost the meaning of existence, the function of the multinational companies and international organizations will be strengthened, human gradually into the era of "global governance" or "world government". At the same time, the arrival of the Internet era also makes the world a "global village", the traditional sense of the territory is increasingly vague, the function of the state is weakened, and the concept of sovereignty is diluted. In this context, patriotism seems out of place, even against the world trend. 00 after college students due to the limited knowledge, experience and life experience, these errors can't correctly understand propaganda thought intention, perhaps even put these wrong ideas to accept as a truth, so if you don't correct guidance and improve their thinking, strengthen their patriotism education, the erroneous ideas will creep in, not only will weaken people's responsibility to bear, to reduce people's will to fight, but also eroded the ideal faith of people including people loyal to the country, the national identity.

\subsubsection{Some Practical Problems in China}

Since the founding of new China, forty years of reform and opening up have witnessed earth-shaking changes in the domestic situation and contradictions in China. The report to the 19th national congress declared that "socialism with Chinese characteristics has entered a new era," and that "the principal contradiction in our society in the new era has been transformed into a contradiction between unbalanced and inadequate development and the people's growing needs for a better life." Socialism with Chinese characteristics has entered a new stage of development and achieved a historic leap from standing up and becoming rich to becoming strong. However, there are still a lot of practical problems in our country that have not been well solved. For example, the gap between the rich and the poor is still large, environmental pollution is relatively serious, housing prices are rising rapidly, food and drug safety problems are worrying, it is difficult for college students to find jobs and so on. These problems have shaken college students' confidence in China's de- velopment prospects.

\subsection{The Group Characteristics of Post-00s College Students Themselves Bring Challenges to Patriotism Education}

In the fall of 2018 , the post-00s generation entered college campuses as an official group. According to the big data of freshmen registration at various universities, nearly three-quarters of the undergraduate freshmen at various universities in 2018 were born after 2000. The post-00s have some group characteristics endowed by The Times, which bring challenges to their patriotic education.

\subsubsection{Strong Individual Consciousness and Pursuit of Personalized Value of Post-00s College Students}

" 00 " after the vast majority of college students was born in " 421 " family environment, they grew up the love of parents and elders, many children who has never tasted what is bitter, rarely even did not take part in labor, so that children to self-centered, relatively selfish, lack of collective sense, more utilitarian and reality, today's society is open, free at the same time, thought and culture diversity, also therefore grew up 00 after college students of this age are more likely to pursue the value of personalization. For college students born after 2000, let them understand that there is a country to have a home, the country behind, will also be bullied, the country will be strong talents, to focus on training

\subsubsection{Networked Entertainment, Study and Life Mislead Them by Some Negative Values in the Network}

Born and raised in the Internet era, college students born in the 2000s are far more likely to use, contact and understand online media than those born in the 1990s. Their daily life, entertainment and study are inseparable from the Internet, the network has a great impact on them. Especially in the relatively free speech today, there are also some comments that do not conform to the facts on the Internet, such as some malicious attacks on the party and the country or some leaders, some students will be misled. College students born in the 2000s are generally more interested in entertainment news, such as Tik Tok, and indifferent to national or current affairs, which is very worrying. Due to the lack of knowledge, life experience is still shallow, the lack of rational judgment of some information on the Internet, it is easy to be encouraged by some words of others or be used by others, so as to make some extreme behavior or irrational behavior. 


\subsubsection{College Students Born after 2000 Have a Life Ideal of Aiming High, But Lack the Spirit of Practical Work}

After 90 college students and the compared after 00, can say they are well informed, have big dreams and revenge, but in their lack of detailed planning, more the lack of one step a footprint, steadfast to strive, ready to present their determination and courage, visionary, lack of practice exercise, also lack of pragmatic spirit, on them have a strong sense of patriotism. They will feel proud for the prosperity of the motherland today, will be aggrieved injustice against in the world, but in their minds just like those great men do vigorous event is patriotic, are often reluctant to start from around things, patriotism is precisely from the nearby small practice training. Invention, creation, defend the motherland is patriotic, but as college students now steadfast study of science and culture is patriotic, to teach is also patriotic. Therefore, the patriotic education of post-00s college students is to teach them to start from learning, start from the small things around, to be a down-to-earth person, down-to-earth work, to learn the real skills, to bear the responsibility for the development of the country and the nation.

\section{Path Analysis of Patriotism Education of Post-00s College Students}

\subsection{Carry out Ideological and Political Education on College Students with Effective Carrier}

\subsubsection{Attach Importance to the Carrier of Ideological and Political Education Theory Courses and Specialized Courses in Colleges and Universities}

Through the course, students can strengthen their mastery of theory and improve their theoretical cognition, which mainly includes the following contents:

We will strengthen education on the conditions of the country, the world and the party. The education of national conditions is to let students learn about the actual situation of the country from facts and establish a correct view of national conditions. To understand the achievements and problems in China's current construction; to understand the world is to see that the world is constantly changing and unpredictable. Countries with relatively weak comprehensive strength in politics, economy, culture, science and technology will face a variety of external risks and internal challenges.

To understand the world situation, we should also have a correct understanding of the capitalist society and the capitalist system. Such a system has certain advantages at present, but we should also clarify the nature of the capitalist system, recognize the contradictions that cannot be overcome by capitalism itself, and learn to make a correct judgment, so as to avoid blind worship of the west or capitalism. Through the understanding of the national conditions and the world situation is not only to enhance students' national pride, but also to have a sense of national crisis.

To strengthen the study of Chinese history and traditional culture among post-00s college students. Some post-00s college students know and yearn for the western culture, but they are very unfamiliar with the culture of their own country. The real reason for these phenomena is that our college students lack correct history education $^{[4]}$. Every page of the 5,000-year history of Chinese civilization records the resounding power of patriotism, every page flashes the immortal glory of patriotism, and every page vividly illustrates the firm value pursuit of the Chinese people. Visit historical sites and feel the changes of the country's world. The students can happily sit in the classroom today is the history of countless patriotic people with sweat, tears, blood and life to defend. In the face of the crisis of national extinction, the sons and daughters of the Chinese nation united in their resolve to resist foreign aggression, fight for the nation, fight for the motherland, fight for dignity, and gather a mighty patriotic force.

We should carry forward and protect China's material and intangible cultural heritage. Attach importance to traditional Chinese festivals, such as the Dragon Boat Festival. Nowadays, there are many students who do not know and care about the traditional festivals in their own countries, but are keen on celebrating some foreign festivals, such as Christmas. To remember the country's important anniversaries, such as September 18, Nanjing massacre Memorial Day. Remember this day not to remember the hatred, but to inspire students to move on, to build a strong country. We should also cherish and protect the material and cultural heritage left by our ancestors, such as the terra-cotta warriors, the Great Wall, the Forbidden City and the Mogao grottoes in Dunhuang.

\subsubsection{Strengthen Patriotism Education by Using Counselors or Head Teachers to Carry Out Daily Ideological and Political Education}

To strengthen patriotism education, it is necessary to make use of various ways and opportunities throughout the study, life and daily ideological and political education. For example, military training is a good opportunity for new students to grasp the opportunity to strengthen the knowledge of national defense education; the annual selection and distribution of state grants and scholarships 
reflect the care and concern of the party and the state for students. Students can also use a variety of social practice, innovation and entrepreneurship exercise down-to-earth, down-to-earth life, work; Class teachers and counselors can organize patriotic class meetings or speeches to promote students' patriotic feelings.

\subsubsection{Use the Network Carrier To Conduct New Patriotism Education}

The general trend of network patriotism is good, but there are still some problems affecting the healthy development of network patriotism, so it is necessary to strengthen the cultivation of network patriotism. Internet patriotism is a new form of patriotism, and it is also an important way for post-00s college students to show patriotism and educate patriotism. It integrates patriotism into students' daily online life. Students born after 2000 can give full play to their advantages, design micro-video, audio, cartoon, H5 and other micro-products by themselves or by forming a team, and synchronously spread the patriotic deeds of great men by relying on the new media matrix and Tik Tok, some famous new media portals. Not only enriched their knowledge, and in the network propaganda, feel patriotism.

However, at the same time, it is necessary to strengthen Internet supervision and determine the standards for auditing and supervision. The government should vigorously curb Internet rumors, never tolerate false propaganda and false reports, and severely punish those ACTS that maliciously subvert China, deliberately defile the national image, or create incidents out of nothing to harm the interests of the people. We will resolutely implement the general requirements for building a new era, take the party's political development as the central task and give top priority to it, make solid progress in the fight against corruption, constantly improve the quality of the Internet, and work hard to promote comprehensive and rigorous governance of the party, thus providing a fundamental guarantee for reform, opening up and modernization.

\subsection{Cultivate the International Patriotic Spirit of Post-00s College Students}

With the trend of world economic globalization and information integration, as well as the implementation of One
Belt And One Road, patriotism is endowed with more contents of The Times and global characteristics. Patriotism in the new era should overcome the tendency of narrow nationalism. College students born after 2000 should face the world and move towards the future with a more open and inclusive mind? While inheriting and carrying forward the fine traditional culture of the Chinese nation, we should actively spread and carry forward the fine culture of the Chinese nation, and at the same time, we should learn from and absorb the fine achievements of the civilizations of the world, including those created under the capitalist system. As a youth, college students should have their feet on the ground after 00, cherish good time, of the university of based on their own practice, based on their own, look around the world, to learn scientific and cultural knowledge, learning the advanced technology, to arm themselves with knowledge, train for the best talent, to have the opportunity to serve the motherland in the future, also have a chance out of their country, to participate in global governance: such as environmental pollution, stability and common prosperity of the world development, etc.

\section{Conclusion}

Of course, patriotic education is the result of a concerted effort by the country, the society, the school, the family and the individual. It is not overnight, but gradually cultivated in life and practice.

\section{References}

[1] Literature Research Office of the CPC Central Committee, Edited by Xi Jinping on the Construction of Socialist Culture [M]. Beijing: Central Literature Press, 2017.

[2] Selected Works of Mao Zedong [M]. Beijing: People's Publishing House, 1991.

[3] Lin Bohai. National Patriotism Education in the Era of Globalization [J]. 2002.

[4] Tao mao-ping. The Important Role of History Education in Patriotism Education [J]. Journal of Social Science, Human Normal University, 1983 (4): 41-48. 